\title{
Zinc sulphate or zinc nanoparticle applications to leaves of green beans
}

\author{
Jaime Bautista-Diaz, Oscar Cruz-Alvarez ${ }^{1}{ }^{1}$, Ofelia Adriana Hernández-Rodríguez ${ }^{1 \oplus}$,

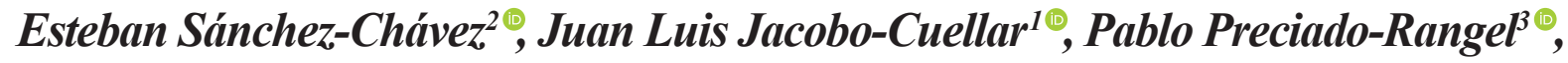 \\ Graciela Dolores Avila-Quezada ${ }^{1 \oplus}$, Damaris Leopoldina Ojeda-Barrios ${ }^{1 * \odot}$
}

\author{
${ }^{1}$ Facultad de Ciencias Agrotecnológicas, Universidad Autónoma de Chihuahua, Chihuahua, México \\ ${ }^{2}$ Centro de Investigación en Alimentación y Desarrollo A. C., Delicias, Chihuahua, México \\ ${ }^{3}$ Instituto Tecnológico de Torreón, Instituto Tecnológico Nacional de México, Torreón, Coahuila, México
}

\begin{abstract}
The green bean (Phaseolus vulgaris L.) is a very widely grown food crop that contributes significantly to human dietary needs in many countries due to its high content of protein. This study evaluates foliar applications of $\mathrm{ZnSO}_{4}$ versus that of zinc oxide nanoparticles ( $\mathrm{ZnO}$ NPs) to leaves of the green bean cv. 'Strike' and records the plant responses in terms of $\mathrm{Zn}$ uptake and concentrations of photosynthetic pigments and bioactive compounds. The experiment was conducted under greenhouse conditions in Chihuahua, Mexico, with a completely randomised experimental design with 10 replicates. The two treatments were foliar applications of either an aqueous solution of $\mathrm{ZnSO}_{4}$ or an aqueous suspension of $\mathrm{ZnO}$ NPs (both $150 \mathrm{mg} \cdot \mathrm{L}^{-1}$ ). The application of $\mathrm{ZnO}$ NPs significantly increased concentrations of $\mathrm{Zn}^{2+}$ in the leaflets, roots, stems and pods of chlorophylls $a$ and $b$ (values $15.40 \mu \mathrm{g} \cdot \mathrm{g}^{-1}$ and $11.64 \mu \mathrm{g} \cdot \mathrm{g}^{-1}$, respectively). Sucrose concentration was also increased by $\mathrm{Zn}^{2+}$ applications, but no differences were found in total phenols (TP), total flavonoids (TFl) or antioxidant capacity (AC). In the pods and seeds, $\mathrm{Zn}^{2+}$ application left sucrose and TFl concentrations unchanged, but the TP increase was significant. The AC was affected by both zinc sources and only in the pods. The applications of $\mathrm{ZnSO}_{4}$ or $\mathrm{ZnO} \mathrm{NPs}$ significantly increased the biomass accumulation $\left(79.10 \mathrm{~g} \cdot \mathrm{p}^{-1}\right.$ and $\left.84.70 \mathrm{~g} \cdot \mathrm{p}^{-1} \mathrm{DW}\right)$ and yield $\left(55.64 \mathrm{~g} \cdot \mathrm{p}^{-1}\right.$ and $\left.53.80 \mathrm{~g} \cdot \mathrm{p}^{-1} \mathrm{FW}\right)$. These results suggest that the application of ZnO NPs could represent a worthwhile biofortification strategy in the commercial production of green bean cv. 'Strike'.
\end{abstract}

Keywords: antioxidant capacity, efficiency, fertilisation, nanofertilisers, Phaseolus vulgaris L.

Abbreviations: AC, antioxidant capacity; BBCH Biologische. Bundesanstalt, Bundessortenamt und CHemische Industrie; Chl. Chlorophyll; DPPH, 2,2-diphenyl-1-picrylhydrazyl; EDTA, Ethylenediaminetetraacetic acid; ROS, reactive oxygen species; SOD, superoxide dismutase; TAn, total anthocyanins; TC, total carotenoids; TFl, total flavonoids; TP, total phenols; ZnO NPS, zinc oxide nanoparticles; $\mathrm{ZnSO}_{4}$, zinc sulphate.

\section{INTRODUCTION}

The productivity of agricultural crops is closely related to optimisation of the mineral nutrient availability in the root zone (Souri and Hatamian, 2019). To achieve this, fertilisers are applied to the soil (Raliya et al.,
2018); however, fertiliser performance can be reduced by various factors including soil-water content and irrigation practices, soil $\mathrm{pH}$, soil texture and soil structure, water solubility of the fertiliser and fertilisation rates 
(Singh et al., 2017; Souri et al., 2017; Souri et al., 2018; Hatamian et al., 2018). Foliar fertilisation of mineral nutrients can also be an appropriate technique to overcome minerals deficiency or to increase their contents in agriculture products (Souri and Dehnavars, 2017; Aslani and Souri, 2018; Mazaheri-Tirani et al., 2019). The efficiency of foliar application of fertilisers can also be a function of the environmental factors (temperature, light intensity and relative humidity) and plant structure (the presence of waxes, cuticle thickness and composition). These environmental and plant factors can also interact to increase or decrease the foliar fertilisation efficiency (Bonomelli et al., 2021).

The green bean (or the 'common bean' or 'French bean', Phaseolus vulgaris L.) is a vegetable which enjoys widespread popularity. The popularity of its immature pods and seeds can be attributed to their high content of minerals $\left(\mathrm{Ca}^{2+}, \mathrm{Fe}^{2+}, \mathrm{Zn}^{2+}, \mathrm{Mg}^{2+}\right.$ and $\left.\mathrm{P}\right)$ and also of carbohydrates, proteins, fibre, calories and vitamin B (Sida-Arreola et al., 2015; Souri and Aslani, 2018; Sálcido-Martínez et al., 2020). However, the cultivation of this species extends to areas of the world in which the soils are well suboptimal for it due to the presence of (e.g.) high levels of carbonates, or salinity, or adverse physical properties (Minnocci et al., 2018; Balafrej et al., 2020). Under adverse soil conditions, deficiencies of some micronutrients can increase, including that of $\mathrm{Zn}^{2+}$ which reduces both the yield and quality of the harvested product (Korkmaz et al., 2018). Zinc is an essential micronutrient for fruit set (Minnocci et al., 2018). It actively participates as a cofactor in the synthesis of DNA and proteins and plays an important role in gene expression in stress tolerance (Korkmaz et al., 2018; Ponce-García et al., 2019). For these reasons, $\mathrm{Zn}^{2+}$ is supplied mainly via edaphic or foliar applications of $\mathrm{Zn}\left(\mathrm{NO}_{\mathrm{s}}\right)_{2}, \quad \mathrm{ZnSO}_{4}$ or chelates (e.g. EDTA-Zn) (Pedruzzi et al., 2020). However, their foliar uptake efficiency is relatively low because $\mathrm{Zn}^{2+}$ absorption by the leaf depends on the chemical nature of the source (García-López et al., 2019).

After $\mathrm{Fe}, \mathrm{Zn}$ is the most abundant transition metal element in living organisms (Castillo-González et al., 2018). It plays a major role in plant metabolism because it is an essential component of several key enzymes, including oxidoreductases, lyases, isomerases, transferases, hydrolases and ligases (Ojeda-Barrios et al., 2019; Akanbi-Gada et al., 2019). Zinc is also an essential micronutrient for the growth and development of cultivated plants and generally requires concentrations in the range of $15-20 \mathrm{mg} \cdot \mathrm{kg}^{-1}$ (Ewais et al., 2017). Moreover, $\mathrm{Zn}$ is involved in tryptophan synthesis, auxin metabolism, cell division and chlorophyll synthesis. It is also involved in pollen development and fruit set (Pedruzzi et al., 2020; Balafrej et al., 2020; BalandranValladares et al., 2021).

A further advance in foliar fertilisation is the use of nano-technologies, since the transformation of macro minerals to nano-sized particles (NPs, size $<100 \mathrm{~nm}$ ) leads to useful characteristics for the application of micronutrients (Ghidan et al., 2020). Foliar spraying of 'nanofertilisers' (Nfs) increases the nutrient availability, thus reducing disease incidence and increasing crop quality and yield (Sálcido-Martínez et al., 2020). Compared with conventional fertilisers, NPs can reduce product wastage and so minimise impacts on the environment (soil and groundwater contamination) (Fatollahpour-Grangah et al., 2020). However, the use of nanosuspensions can lead to their deposition on the leaf surface, generate toxicity problems and this affects their uptake (Akanbi-Gada et al., 2019).

A number of studies have demonstrated the effectiveness of applications of zinc oxide nanoparticles ( $\mathrm{ZnO} \mathrm{NPs}$ ) on germination, biomass accumulation, photosynthetic pigments and enzyme activity (Singh et al., 2017; Rossi et al., 2019). A further advantage is that NPs can be supplied in smaller concentrations with similar or better results than the larger doses used for conventional soil-surface fertilisation (Mazaheri-Tirani et al., 2019). However, excessive use of NPs can cause stress to plants, affecting the synthesis of proteins, carbohydrates and DNA (Abbasifar et al., 2020). The uptake efficiency of NPs is determined by their chemical composition, shape, reactivity, $\mathrm{pH}$, degree of adsorption and the area of leaf surface covered (Marzouk et al., 2019).

Foliar applications of NPs of $\mathrm{ZnSO}_{4}$ and $\mathrm{ZnO}$ have been reported to be practical measures that can achieve better physiological and biochemical plant responses, while also minimising environmental impacts by reducing the number of applications (Pullagurala et al., 2018; Nafady et al., 2019). With an increasing demand for beans as a staple of human nutrition, the generation of further information on the use of $\mathrm{Zn}^{2+}$, including its uptake and impact on biofortification are essential to meet the needs of both the producers and consumers of this legume (Sida-Arreola et al., 2015; Ewais et al., 2017). The objective of this study was to evaluate foliar applications of $\mathrm{ZnSO}_{4}$ and $\mathrm{ZnO}$ NPs to compare responses in terms of $\mathrm{Zn}$ uptake, concentrations of the photosynthetic pigments and bioactive compounds in the bean cv 'Strike'.

\section{MATERIALS AND METHODS}

\section{Experimental site, crop management and experimental design}

For this study, plants of the green bean (P. vulgaris L.) cv. 'Strike' (short cycle variety, sensitive to salinity and adapts to greenhouse conditions) were grown in polyethylene bags filled with $3 \mathrm{~kg}$ of soil (sandy loam, $\mathrm{pH} 6.8$, electrical conductivity $0.51 \mathrm{dS} \cdot \mathrm{m}^{-1}$, organic matter $1.5 \%$, water saturation $48 \%$ ) (Figure 1). The soil composition contained the micronutrients in $\mathrm{mg} \cdot \mathrm{kg}^{-1}$ : $0.22 \mathrm{Zn}^{+2}, 0.4 \mathrm{Cu}^{+2}, 5.4 \mathrm{Fe}^{+2}$ and $1.3 \mathrm{Mn}^{+2}$. Plants were raised in an experimental greenhouse in Chihuahua, Mexico (28 $\left.41^{\prime} 29.8^{\prime \prime} \mathrm{N}, 106^{\circ} 06^{\prime} 58.6^{\prime \prime} \mathrm{W}\right)$ with a mean 

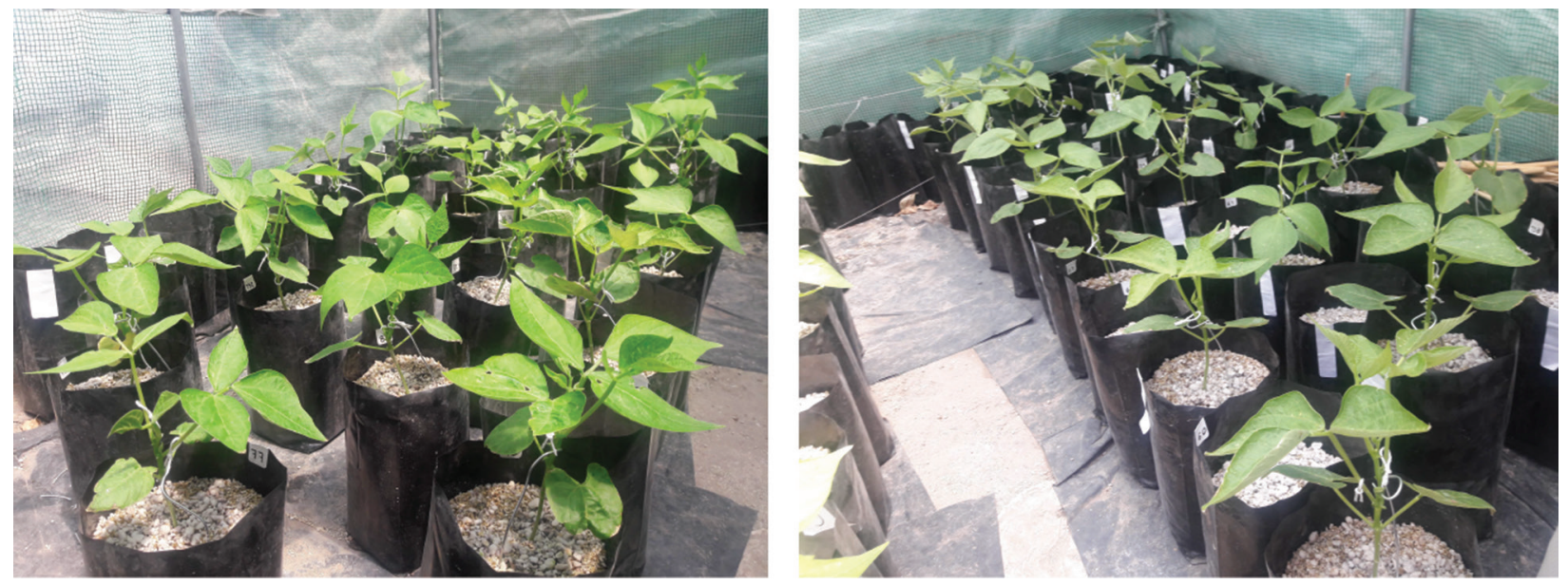

Figure 1. Green beans cv. 'Strike’ plants under greenhouse conditions at Universidad Autónoma of Chihuahua, Mexico.

temperature of $30{ }^{\circ} \mathrm{C}$. Mineral nutrition was carried out using a solution prepared with distilled water and containing the macronutrients $(\mathrm{mM}): 7.5 \mathrm{NH}_{4} \mathrm{NO}_{3}, 1.0$ $\mathrm{K}_{2} \mathrm{HPO}_{4}, 1.05 \mathrm{~K}_{2} \mathrm{SO}_{4}, 2.5 \mathrm{CaCl}_{2} \cdot 2 \mathrm{H}_{2} \mathrm{O}, 1.0 \mathrm{MgSO}_{4}$ and the micronutrients $(\mu \mathrm{M}): 44.6 \mathrm{MnSO}_{4} \cdot \mathrm{H}_{2} \mathrm{O}, 1.2 \mathrm{ZnSO}_{4} \cdot 7 \mathrm{H}_{2} \mathrm{O}$, $0.185 \mathrm{CuSO}_{4} \cdot 5 \mathrm{H}_{2} \mathrm{O}, 0.06(\mathrm{NH} 4)_{6} \mathrm{Mo}_{7} \mathrm{O}_{24} \cdot 4 \mathrm{H}_{2} \mathrm{O}$ and 0.5 $\mathrm{H}_{3} \mathrm{BO}_{3}$ (Ponce-García et al., 2019).

We used a completely randomised experimental design with 10 replicates, where the experimental unit consisted of one plant. There were two $\mathrm{Zn}$ treatments and a control (without $\mathrm{Zn}$ ). The first $\mathrm{Zn}$ treatment used an aqueous solution of $\mathrm{ZnSO}_{4}\left(150 \mathrm{mg} \cdot \mathrm{L}^{-1}\right.$, Merck ${ }^{\circledR}$, Germany) and the second an aqueous suspension of $\mathrm{ZnO}$ NPs (Investigación y Desarrollo de Nanomateriales S.A. de C.V., Mexico). Both treatments were applied before sunrise using a soft brush to the upper and lower surfaces of the first trifoliate leaves. To avoid any contact with the soil, each plant was sprayed separately, and a plastic film was used to cover the top of each pot before spraying. Foliar application was done every 10 days for a total of three applications. After physiological maturity of the plants, at $60 \mathrm{DAG}$, the samples were taken and separated into four parts: root, stem, leaf, and fruit and washed thrice with distilled water and $1 \%$ non-ionic detergent.

\section{Characterisation of the $\mathrm{Nfs}$}

The material applied as Nfs was $\mathrm{ZnO}$ obtained by wet chemistry method in the form of wurtzite crystals with an average size of $50 \mathrm{~nm}$ with negligible contaminants, a purity level of $99.7 \%$ and a density of $5.61 \mathrm{~g} \cdot \mathrm{cm}^{-3}$ (Figure 2 and 3) (Ponce-García et al., 2019).

\section{Parameters evaluated}

\section{Zinc concentration (leaflet, stem, root and pods)}

Prior to analysis, the plant was separated into leaflets, stems, roots and pods. The determination of $\mathrm{Zn}^{2+}$ concentration in these plant organs was carried out following the method of Rossi et al. (2019) with slight modifications. Briefly, the different plant organs were placed in a container with $150 \mathrm{~mL}$ of distilled water and left to stand for 5 min before washing again, but with a $4 \mathrm{~N} \mathrm{HCl}$ solution $\left(1 \mathrm{~mL} \cdot \mathrm{L}^{-1}\right)$ and rinsed with distilled water to remove any superficial $\mathrm{Zn}$ residues. This wash water was then made up to $200 \mathrm{~mL}$ and filtered through Whatman Paper No. 1.

Organ samples were then dried in a Heratherm VCA $230^{\circledR}$ (Thermo Scientific, USA) oven at $70^{\circ} \mathrm{C}$ for $72 \mathrm{~h}$ (leaflets, stems and roots) or for $144 \mathrm{~h}$ (pods). Each sample was then homogenised in a Willey R-TE-650/1 mill with a 1-mm mesh (Tecnal, Piracicaba, Brazil) and the homogenate was placed in an airtight container and held at $-20{ }^{\circ} \mathrm{C}$ for further analysis. Subsamples of $1 \mathrm{~g}$ of fresh weight of homogenate were then taken and digested in $25 \mathrm{~mL}$ of a triacid mixture $\left(\mathrm{HNO}_{3}, \mathrm{HCl}\right.$ and $\mathrm{H}_{2} \mathrm{SO}_{4}$ ), filtered with Whatman Paper No. 1 and made up to $50 \mathrm{~mL}$ with tri-distilled water. Zinc concentrations were then determined with an atomic absorption spectrophotometer (Thermo Scientific, USA). The results are expressed in $\mathrm{mg} \cdot \mathrm{kg}^{-1}$ dry weight.

\section{Chlorophyll and total carotenoids}

The concentrations of chlorophyll $a$ (chl $a$ ) and chlorophyll $b$ (chl $b$ ) and total carotenoids were determined by the method of Ponce-García et al. (2019), which requires weighing $0.2-0.3 \mathrm{~g}$ of fresh photosynthetic material (leaflets) to which $10 \mathrm{~mL}$ of pure methanol $\left(\mathrm{CH}_{3} \mathrm{OH}\right)$ was added. The samples were then incubated at room temperature in darkness for $24 \mathrm{~h}$. After this period, absorbance was measured at $470 \mathrm{~nm}$ (carotenoids), $653 \mathrm{~nm}$ (chl $b$ ) and $666 \mathrm{~nm}$ (chl $a$ ). The results are expressed as $\mu \mathrm{g} \cdot \mathrm{g}^{-1}$.

\section{Bioactive compounds (leaflet, pod and seed) \\ Extract preparation and determination}

Extraction of bioactive compounds was carried out following the method of Cera-Campos et al. (2019) with slight modifications. Fresh samples $(0.5 \mathrm{~g})$ were homogenised with $5 \mathrm{~mL}$ of $80 \%$ (v:v) methanol. The homogenised sample was centrifuged at $6,000 \mathrm{rpm}$ for $10 \mathrm{~min}$ at $4{ }^{\circ} \mathrm{C}$. The supernatant was used to quantify 

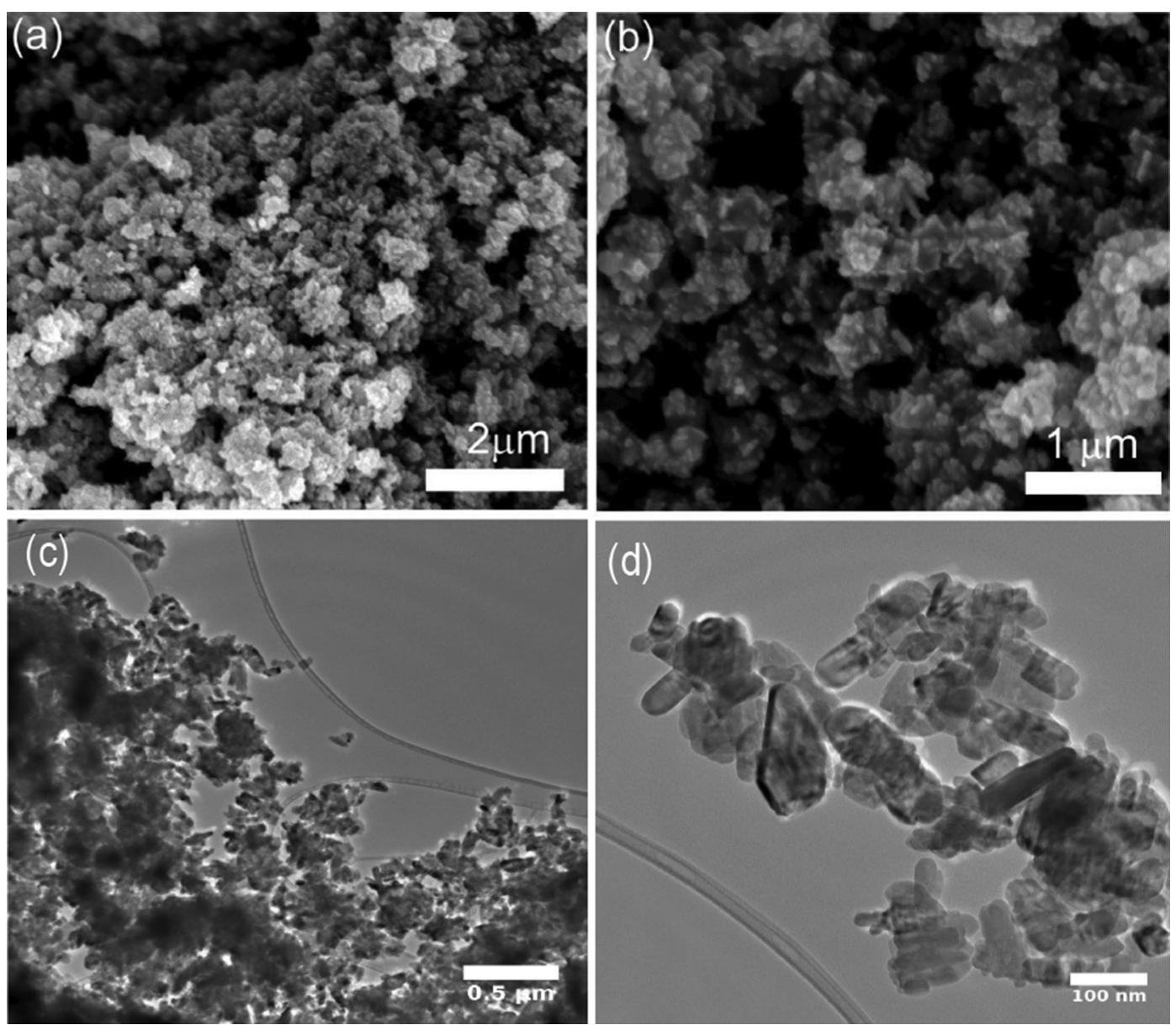

Figure 2. (A and B) Sample morphology of ZnO NPs by scanning electron microcopy and (C and D) transmission electron microscopy (Ponce-García et al., 2019). NPs, nanoparticles.
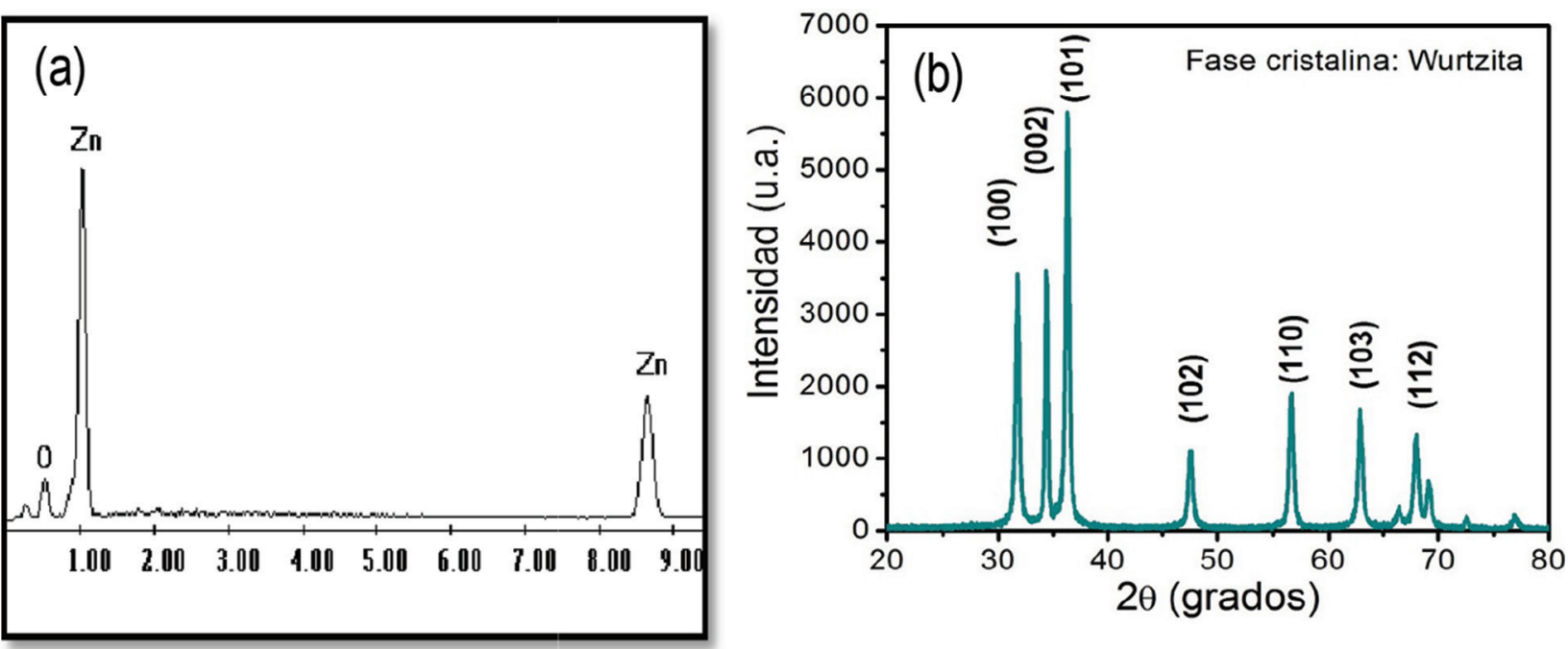

Figure 3. (A) Elemental analysis (chemical composition) by energy dispersive X-ray scattering and (B) crystalline structure by X-ray diffraction of the sample ZnO NPs (Ponce-García et al., 2019). NPs, nanoparticles.

the phenols, flavonoids, anthocyanins and antioxidant capacity (AC). Total phenols (TP) were quantified according to the Folin-Ciocalteu method described by Monroy-Gutiérrez et al. (2017). Two samples were taken with $0.250 \mathrm{~mL}$ of the supernatant to which $0.750 \mathrm{~mL}$ and $0.250 \mathrm{~mL}$ of $2 \%$ and $50 \%$ (v:v) $\mathrm{Na}_{2} \mathrm{CO}_{3}$ and Folin-Ciocalteau were added, respectively. The mixture was incubated for $1 \mathrm{~h}$ and the absorbance was measured at $725 \mathrm{~nm}$ on a Lambda $25^{\circledR} \mathrm{UV}$-visible spectrophotometer (PerkinElmer, Waltham, USA). The results are expressed in $\mathrm{mg}$ GAE $\cdot 100 \mathrm{~g}^{-1}$. Total flavonoids (TFl) were quantified according to the method 
of Chang et al. (2002). Here, $0.250 \mathrm{~mL}$ of supernatant was added to $0.075 \mathrm{~mL}$ of $\mathrm{NaNO}_{2}$, the mixture was shaken vigorously for $5 \mathrm{~min}$, then $0.150 \mathrm{~mL}, 0.500 \mathrm{~mL}$ and $2.025 \mathrm{~mL}$ of $\mathrm{AlCl}_{3}, \mathrm{NaOH}$ and deionised water were added, and the mixture was left to stand for $40 \mathrm{~min}$, after which the absorbance was determined at $510 \mathrm{~nm}$ (PerkinElmer, Waltham, USA). The results are expressed as $\mathrm{mg} \mathrm{EC} \cdot 100 \mathrm{~g}^{-1}$. The total anthocyanins (TAn) were determined using the differential $\mathrm{pH}$ method described by Giusti and Wrolstad (2001) with slight modifications. Two aliquots of $0.500 \mathrm{~mL}$ of supernatant were taken. To one aliquot was added $2 \mathrm{~mL}$ of $\mathrm{KCl}$ and to the second, $2 \mathrm{~mL}$ of $\mathrm{CH}_{3} \mathrm{COONa}$, and shaken vigorously for $1 \mathrm{~min}$. After this, the absorbances were measured at $460 \mathrm{~nm}$ and $710 \mathrm{~nm}$, respectively (PerkinElmer, Waltham, USA). The results are expressed as mg ocyanidin-3-glucoside $\cdot 100 \mathrm{~g}^{-1}$. AC was determined by the 2,2-diphenyl-1-picrylhydrazyl (DPPH) method described by Cera-Campos et al. (2019) with some modifications. To $0.3 \mathrm{~mL}$ of extract, $5.7 \mathrm{~mL}$ of the DPPH compound was added (DPPH, concentration $\left.0.0375 \mathrm{~g} \cdot \mathrm{L}^{-1}\right)$. The mixture was kept in the dark for $30 \mathrm{~min}$. The decrease in the DPPH radical was measured at $515 \mathrm{~nm}$ (PerkinElmer, Waltham, USA). The results are expressed as\% DPPH inhibition.

\section{Sucrose (leaf, pod and seed)}

The non-structural carbohydrate was quantified according to the method of Irigoyen et al. (1992) with slight modifications: Briefly, $0.5 \mathrm{~g}$ of fresh plant material was taken and homogenised thrice, the first time with $5 \mathrm{~mL}$ of $96 \%$ ethanol and then twice with $5 \mathrm{~mL}$ of $70 \%$ ethanol. The homogenate was centrifuged at $3,740 \mathrm{~g}$ for $10 \mathrm{~min}$ at $4{ }^{\circ} \mathrm{C}$. An amount of $0.1 \mathrm{~mL}$ was taken and $3 \mathrm{~mL}$ of anthrone solution dissolved in $\mathrm{H}_{2} \mathrm{SO}_{4}(1 \mathrm{~g}$ anthrone in $100 \mathrm{~mL} \mathrm{H}_{2} \mathrm{SO}_{4}$ ) was added. It was then placed in a water bath for $10 \mathrm{~min}$, allowed to cool and the absorbance was determined at $650 \mathrm{~nm}$ (PerkinElmer, Waltham, USA). The results are expressed in $\mathrm{mg} \cdot \mathrm{g}^{-1}$.

\section{Yield and biomass}

Fruit yield was determined at the end of the phenological cycle. The results are expressed in grams of fresh weight per plant $\left(\mathrm{g} \cdot \mathrm{p}^{-1} \mathrm{FW}\right)$. Biomass was determined according to the method indicated by Sida-Arreola et al. (2015). In each sampling, the fresh weight of leaflets, stems and roots were taken and dried in a Heratherm VCA $230^{\circledR}$ (Thermo Scientific, USA) oven at $70{ }^{\circ} \mathrm{C}$ for $72 \mathrm{~h}$. The results are expressed in grams of dry weight per plant $\left(\mathrm{g} \cdot \mathrm{p}^{-1} \mathrm{DW}\right)$.

\section{Statistical analyses}

Prior to the statistical analysis, Levene's test for homogeneity of variances was carried out for each group of data per variable (Sokal and Rohlf, 1995). Subsequently, the analysis of variance was carried out and when a significant treatment effect was detected, Tukey's multiple comparison of means test was applied $(p \leq 0.05)$. In all cases, the statistical program IBM SPSS Statistics 25 was used.

\section{RESULTS AND DISCUSSION}

\section{Concentration of Zn2+ (leaflets, roots, stems, pods)}

The application of ZnO NPs significantly increased the $\mathrm{Zn}^{2+}$ concentrations in the leaflets, roots, stems and pods with values of $94.66 \mathrm{mg} \cdot \mathrm{kg}^{-1}, 80.30 \mathrm{mg} \cdot \mathrm{kg}^{-1}$, $87.18 \mathrm{mg} \cdot \mathrm{kg}^{-1}$ and $66.29 \mathrm{mg} \cdot \mathrm{kg}^{-1} \mathrm{DW}$, respectively (Figure 4). Except for the stems, the differences between the two treatments were significant. Ranked in order of efficacy, it can be expressed as ZnO NPs > $\mathrm{ZnSO}_{4}>$ control. In this regard, Ponce-García et al. (2019), when evaluating the edaphic application of $100 \mathrm{mg} \cdot \mathrm{kg}^{-1}$ of $\mathrm{Zn}^{2+}$ (sulphate) in the green bean (P. vulgaris L.), reported a significant increase in the concentrations of $\mathrm{Zn}$ in the roots and leaflets with values of $31 \mathrm{mg} \cdot \mathrm{kg}^{-1}$ and $5 \mathrm{mg} \cdot \mathrm{kg}^{-1}$, respectively.

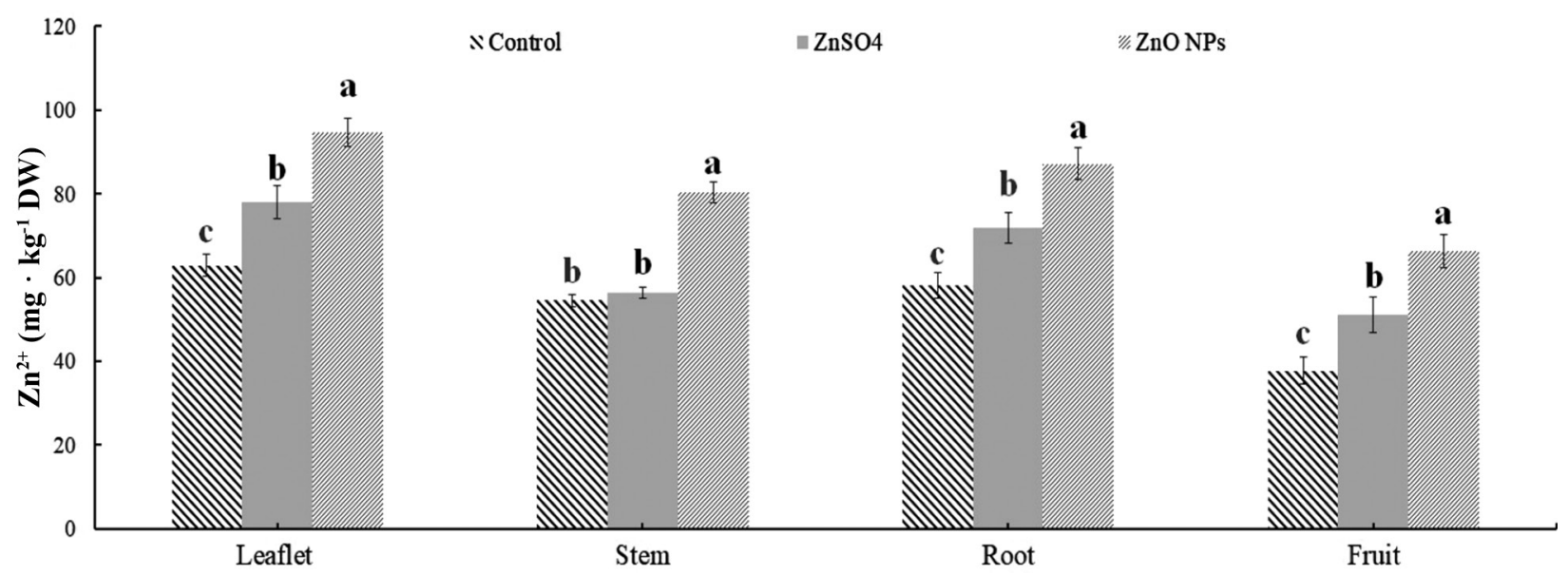

Figure 4. $\mathrm{Zn}^{2+}$ concentrations in leaflet, stem, root and pods of the green bean cv. 'Strike' sprayed with $\mathrm{ZnSO}_{4}$ and $\mathrm{ZnO}$ NPs. The data shown are mean values \pm standard deviations $(n=10)$. Bars with the same letter are not significantly different according to Tukey's test $(p \leq 0.05)$. NPs, nanoparticles. 
In other crops, such as Coffea arabica L., applications of $\mathrm{ZnO}$ NPs increased the concentration of $\mathrm{Zn}^{2+}$ in the leaves but not in the stems or roots (Rossi et al. 2019). The plants used in this study did not show symptoms of $\mathrm{Zn}^{2+}$ deficiency, which could explain the foliar increase due to $\mathrm{Zn}$ micronutrient. On the other hand, it has been reported that the dissolution of ZnO NPs in deionised water is relatively slow, so in $24 \mathrm{~h}$ only $2 \%$ is dissolved, hence its effect can be better observed after 30 days (Singh et al 2017).

In this study, the application of ZnO NPs to the leaves indicates a significant concentration of $\mathrm{Zn}^{2+}$ to the pods, stems and roots. In contrast, in another study (Ponce-García et al. 2019), applications of $25 \mathrm{mg} \cdot \mathrm{kg}^{-1}$, $50 \mathrm{mg} \cdot \mathrm{kg}^{-1}$ or $100 \mathrm{mg} \cdot \mathrm{kg}^{-1}$ of $\mathrm{ZnO}$ NPs on the green bean 'Strike' showed enhancement in the roots but not in the stems. This variation in behaviour may be associated with the phenological stage, nutrient antagonism or applied dose, as indicated by Rossi et al. (2019). On the other hand, pods harvested from plants treated with $\mathrm{ZnO}$ NPs presented higher $\mathrm{Zn}^{2+}$ concentrations at $66.29 \mathrm{mg} \cdot \mathrm{kg}^{-1}$ (Figure 5). This suggests that $\mathrm{ZnO} \mathrm{Nfs}$ could help in the biofortification of green bean of this variety. Similar results were reported for this variety by Ponce-García et al. (2019) with applications of $100 \mathrm{mg} \cdot \mathrm{kg}^{-1}$. In this sense, the use of ZnO NPs improves crop productivity by increasing the uptake efficiency, application accuracy and with less environmental impact (Shang et al., 2019). It has been shown that the level of uptake and translocation of ZnO NPs is associated with the applied dose and the phenological stage (Singh et al., 2017). However, little information is available on the physiological and biochemical effects of $\mathrm{ZnO}$ NPs application with this species.

\section{Photosynthetic pigment concentrations}

Reduced synthesis photosynthetic pigment and accumulation are good indicators of stress or suboptimal growth conditions (Marzouk et al., 2019; Zargar Shooshtari et al., 2020; Ebrahimi et al., 2021). The concentration of photosynthetic pigments (chlorophyll, carotenoids and TAn) are presented in Table 1. The application of ZnO NPs increased the concentrations of chl $a$ and chl $b\left(15.40 \mu \mathrm{g} \cdot \mathrm{g}^{-1}\right.$ and $11.64 \mu \mathrm{g} \cdot \mathrm{g}^{-1}$, respectively) with respect to $\mathrm{ZnSO}_{4}$. Previous studies on the broad bean (Vicia faba L.) with foliar applications of $50 \mathrm{mg} \cdot \mathrm{L}^{-1}$ showed positive results with respect to the total chlorophyll concentration (Ghidan et al., 2020). It is known that most micronutrients such as $\mathrm{Fe}^{2+}, \mathrm{Mn}^{2+} \mathrm{Cu}^{2+}$ and $\mathrm{Zn}^{2+}$ are involved in activation of various metabolic enzymes, including protein and chlorophyll biosynthesis (Sida-Arreola et al., 2015; Castillo-González et al., 2018; Souri et al., 2019; Aghaye-Noroozlo et al., 2019). These results contrast with those reported by Ponce-García et al. (2019) who, when applying ZnO NPs and chelates $\left(25,50\right.$ and $\left.100 \mathrm{mg} \cdot \mathrm{kg}^{-1}\right)$ in nutrient solution, report no significant effects. These authors point out an inverse behaviour between the doses of ZnO NPs and chlorophyll concentration, attributed to the stress generated by the possible toxicity caused by the application of these Nfs to the soil. In our study, no visible symptoms of $\mathrm{Zn}^{2+}$ toxicity (wilting, curling, waving, chlorotic and necrotic spots) were detected (Pullagurala et al., 2018), which could be linked to the slow dissolution of ZnO NPs in deionised water (Rossi et al., 2019).

On the other hand, the concentrations of total carotenoids and anthocyanins were not affected by the application of $\mathrm{ZnO}$ NPs. Previous studies indicate a positive effect on plant productivity by increasing

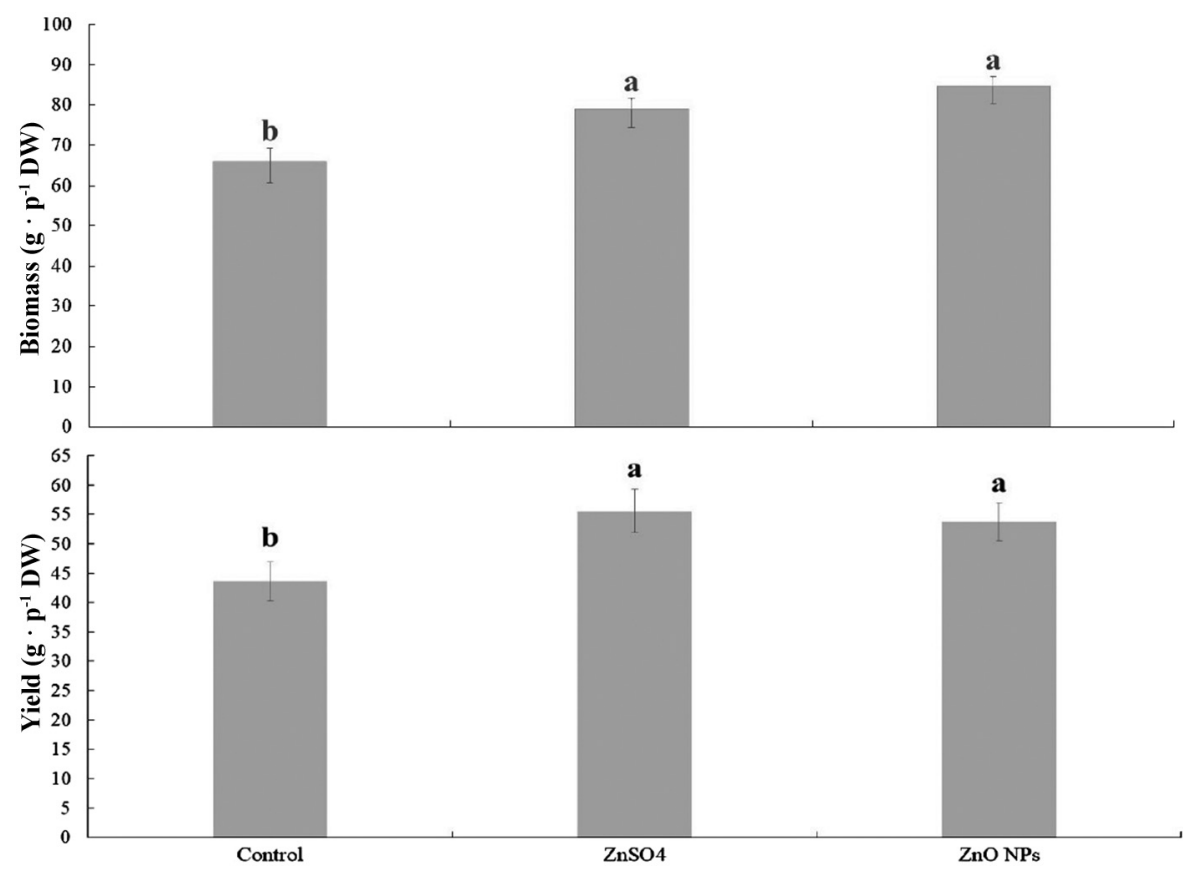

Figure 5. Effect of application of $\mathrm{ZnSO}_{4}$ and $\mathrm{ZnO}$ NPs on biomass accumulation and yield (fresh pods) in the green bean cv. 'Strike'. NPs, nanoparticles. 
Table 1. Changes in concentrations of photosynthetic pigments, bioactive compounds and antioxidant capacities in leaflets of the green bean cv. 'Strike' following applications of $\mathrm{ZnSO}_{4}$ and $\mathrm{ZnO} \mathrm{NPs}$.

\begin{tabular}{|c|c|c|c|c|c|c|c|c|}
\hline \multirow[t]{2}{*}{ Treatment } & \multicolumn{2}{|c|}{ Chl } & \multirow[t]{2}{*}{$\mathrm{TC}$} & \multirow[t]{2}{*}{ TAn } & \multirow[t]{2}{*}{ Sucrose } & \multirow[t]{2}{*}{$\mathrm{TP}$} & \multirow[t]{2}{*}{ TFl } & \multirow[t]{2}{*}{$\mathrm{AC}$} \\
\hline & $a$ & $b$ & & & & & & \\
\hline Control & $11.41 \mathrm{~b}$ & $7.70 \mathrm{~b}$ & $2.91 \mathrm{a}$ & $1.05 \mathrm{a}$ & $5.06 \mathrm{~b}$ & $3.37 \mathrm{a}$ & $0.32 \mathrm{a}$ & $62.90 \mathrm{a}$ \\
\hline $\mathrm{ZnSO}_{4}$ & $12.62 \mathrm{~b}$ & $8.24 \mathrm{~b}$ & $2.14 \mathrm{a}$ & $1.24 \mathrm{a}$ & $6.38 \mathrm{a}$ & $3.55 \mathrm{a}$ & $0.42 \mathrm{a}$ & $72.31 \mathrm{a}$ \\
\hline ZnO NPs & $15.40 \mathrm{a}$ & $11.64 \mathrm{a}$ & $1.58 \mathrm{a}$ & $1.50 \mathrm{a}$ & $5.53 \mathrm{ab}$ & $3.20 \mathrm{a}$ & $0.44 \mathrm{a}$ & $56.57 \mathrm{a}$ \\
\hline
\end{tabular}

Data are expressed on a fresh-weight basis. Values with the same letter within a column are not significantly different according to Tukey's test $(p \leq 0.05)$.

AC, antioxidant capacity (\% DPPH inhibition); Chl, chlorophyll ( $\left.\mu \mathrm{g} \cdot \mathrm{g}^{-1}\right)$; NPs, nanoparticles; TC, total carotenoids $\left(\mu \mathrm{g} \cdot \mathrm{g}^{-1}\right)$; TAn, total anthocyanins (mg cyanidin-3-glucoside $\left.\cdot 100 \mathrm{~g}^{-1}\right)$; Sucrose $\left(\mathrm{mg} \cdot \mathrm{g}^{-1}\right)$; TP, total phenols $\left(\mathrm{mg} \mathrm{GAE} \cdot 100 \mathrm{~g}^{-1}\right)$; TFl, total flavonoids $\left(\mathrm{mg} \mathrm{CE} \cdot 100 \mathrm{~g}{ }^{-1}\right)$; ZnO NPs, zinc oxide nanoparticles.

photosynthesis (Pullagurala et al., 2018; Marzouk et al., 2019); however, there are no specific references indicating changes in the concentrations of carotenoids and TAn for green beans. In this sense, it would be necessary to conduct evaluations with other doses, application times and growth stages to improve our understanding of the effects of NPs on the behaviour of accessory pigments.

\section{Bioactive compounds in leaflets}

In this study, the application of $\mathrm{ZnSO}_{4}$ slightly increased the sucrose concentration $\left(6.38 \mathrm{mg} \cdot \mathrm{g}^{-1}\right)$, but it did not significantly exceed that observed in the treatment with $\mathrm{ZnO}$ NPs $\left(5.53 \mathrm{mg} \cdot \mathrm{g}^{-1}\right)$. The increase in photosynthetic activity is associated with the synthesis and activity of chlorophylls, which allows the accumulation of carbohydrates, including sucrose. Previous reports on green bean indicate that increase in the leaf concentrations of $\mathrm{Mg}^{2+}, \mathrm{Fe}^{2+}$ and $\mathrm{Zn}^{2+}$ affect carbohydrate accumulation (Sálcido-Martínez et al., 2020; Balafrej et al., 2020), which is associated with the participation of these micronutrients in the metabolism of proteins linked to the synthesis and accumulation of chlorophylls (Korkmaz et al., 2018). In general, a gradual increase in the concentration of this soluble sugar was observed in this research. This could be due to the simultaneous need to accumulate and translocate sucrose as a source of carbon and energy to the shoots and pods, as part of the overall growth and development (García-Caparrós et al., 2021).

On the other hand, treating leaflets with $\mathrm{ZnSO}_{4}$ or $\mathrm{ZnO}$ NPs did not affect the concentrations of TP or TFl. To date, there are no reports comparing the effects of $\mathrm{ZnO}$ NPs with $\mathrm{ZnSO}_{4}$ on the accumulations of bioactive compounds in green beans. However, according to our results we infer that the application of $\mathrm{ZnO}$ NPs and $\mathrm{ZnSO}_{4}$ did not significantly modify the physiological and biochemical mechanisms of the plants. The small differences found can be associated with the solubility characteristics of $\mathrm{ZnSO}_{4}$, which when applied to leaves can drop rapidly; therefore, the bioavailability of $\mathrm{Zn}^{2+}$ ions over a prolonged period is uncertain (Doolette et al., 2018). In addition to its physical properties (size, structure and particle shape), previous studies with foliar applications of ZnO NPs varying between $1,000 \mathrm{mg} \cdot \mathrm{L}^{-1}$ and $2,500 \mathrm{mg} \cdot \mathrm{L}^{-1}$ on Brassica nigra and Capsicum chinense indicate a significant effect on FT and TF1 concentrations (Zafar et al. 2016; García-López et al., 2019). On the other hand, Abbasifar et al., (2020) when applying $1,000 \mathrm{mg} \cdot \mathrm{L}^{-1}, 2,000 \mathrm{mg} \cdot \mathrm{L}^{-1}$ or $4,000 \mathrm{mg} \cdot \mathrm{L}^{-1}$ report a significant increase in the concentration of flavonoids in basil leaves (Ocimum basilicum L.). However, it is important to note that the $\mathrm{ZnSO}_{4}$ and $\mathrm{ZnO}$ NPs doses applied in these studies exceed those used in our study by 10 times. According to Zafar et al. (2016), these could induce oxidative stress and stimulate the synthesis of non-enzymatic compounds (phenolic compounds, flavonoids, carotenoids, among others). It is known that under optimal conditions, $\mathrm{Zn}^{2+}$ plays an important role in the synthesis and activation of superoxide dismutase (SOD), the main enzyme associated with the removal of reactive oxygen species (ROS) (Korkmaz et al. 2018). This behaviour changes radically when the concentration of this micronutrient is at phytotoxic levels, causing oxidative stress (García-López et al., 2019). In this sense, the response to foliar $\mathrm{Zn}^{2+}$ application is a function of the species, nutrient status, phenological stage, dose supplied and number of applications (Shang et al., 2019; Abbasifar et al., 2020).

The applications of $\mathrm{ZnSO}_{4}$ and $\mathrm{ZnO}$ NPs showed no effects on AC performance. This result was similar to that observed with foliar concentration of $\mathrm{TFl}$ (Table 2). In contrast, significant increases in AC values have been reported in other species, including basil (O. basilicum L.) (Abbasifar et al., 2020), potato (Solanum tuberosum L.) (Korkmaz et al., 2018) and tobacco (Nicotiana tabacum L.) (Mazaheri-Tirani et al., 2019). Korkmaz et al. (2018) report significant variations in $\mathrm{AC}$ resulting from the interaction between dose and time of application, suggesting that $\mathrm{Zn}^{2+}$ plays a key role in the synthesis and activation of the plant antioxidant system in mitigating oxidative stress (Balafrej et al., 2020).

\section{Bioactive compounds in pods and seeds}

The applications of $\mathrm{ZnSO}_{4}$ and $\mathrm{ZnO}$ NPs showed no significant variation in relation to sucrose concentration in the pod and seeds of green bean. However, TFl concentrations were significant for the seed (Table 2). 
Table 2. Concentrations of sucrose, TP, TFl and AC in pods and seeds of the green bean cv. 'Strike' by supplying $\mathrm{ZnSO}_{4}$ and $\mathrm{ZnO} \mathrm{NPs}$.

\begin{tabular}{llcccc}
\hline Organ & Treatment & Sucrose $\left(\mathrm{mg} \cdot \mathrm{g}^{-1}\right)$ & $\mathrm{TP}\left(\mathrm{mg} \mathrm{GAE} \cdot 100 \mathrm{~g}^{-1}\right)$ & $\mathrm{TFl}\left(\mathrm{mg} \mathrm{CE} \cdot 100 \mathrm{~g}^{-1}\right)$ & $\mathrm{AC}(\%$ DPPH inhibition) \\
\hline \multirow{3}{*}{ Pod } & Control & $10.87 \mathrm{a}$ & $1.96 \mathrm{~b}$ & $0.061 \mathrm{a}$ & $12.36 \mathrm{~b}$ \\
& $\mathrm{ZnSO}_{4}$ & $10.89 \mathrm{a}$ & $1.80 \mathrm{~b}$ & $0.074 \mathrm{a}$ & $18.60 \mathrm{a}$ \\
& $\mathrm{ZnO} \mathrm{NPs}$ & $15.06 \mathrm{a}$ & $2.53 \mathrm{a}$ & $0.092 \mathrm{a}$ & $21.39 \mathrm{a}$ \\
\hline \multirow{3}{*}{ Seed } & $\mathrm{Control}$ & $12.90 \mathrm{a}$ & $2.18 \mathrm{~b}$ & $0.109 \mathrm{a}$ & $71.15 \mathrm{a}$ \\
& $\mathrm{ZnSO}_{4}$ & $14.92 \mathrm{a}$ & $2.16 \mathrm{~b}$ & $0.077 \mathrm{~b}$ & $70.96 \mathrm{a}$ \\
& $\mathrm{ZnO} \mathrm{NPs}^{*}$ & $17.87 \mathrm{a}$ & $4.15 \mathrm{a}$ & $0.136 \mathrm{a}$ & $70.48 \mathrm{a}$ \\
\hline
\end{tabular}

Data are expressed on a dry-weight basis. Values with the same letter within a column are not significantly different according to Tukey's test $(p \leq 0.05)$.

AC, antioxidant capacity; DPPH, 2,2-diphenyl-1-picrylhydrazyl; NPs, nanoparticles; TP, total phenols; TFl, total flavonoids; ZnO NPs, zinc oxide nanoparticles.

These results may be related to the dose and number of $\mathrm{Zn}^{2+}$ applications. Usually, the application of $\mathrm{Zn}^{2+}$ increases the concentrations of nutritional and bioactive compounds, however, information on the effects of applications of $\mathrm{ZnSO}_{4}$ and $\mathrm{ZnO}$ NPs on the concentrations of sucrose and TFl in pods and seeds of green bean is limited. One of the factors offered to explain the high consumption of green beans is their high nutritional value, mineral, fibre, protein, carbohydrate and vitamin contents (Minnocci et al., 2018). However, this crop is highly susceptible to $\mathrm{Zn}^{2+}$ deficiency in soils with high carbonate contents (Doolette et al., 2018; Souri and Aslani, 2018). There is evidence only for leaves, as indicated by Fatollahpour-Grangah et al. (2020); when applying ZnO NPs $\left(1.5 \mathrm{mg} \cdot \mathrm{L}^{-1}\right)$ on pinto beans - cvs 'Coosha', 'Ghaffar' and 'Sadri' - significantly increased the concentrations of soluble sugars. Abbasifar et al. (2020) report a significant increase from $11.09 \mathrm{mg} \cdot \mathrm{g}^{-1}$ to $25.27 \mathrm{mg} \cdot \mathrm{g}^{-1} \mathrm{DW}$ in leaf concentration of TFl by applying $1,000 \mathrm{mg} \cdot \mathrm{L}^{-1}$ and $4,000 \mathrm{mg} \cdot \mathrm{L}^{-1}$ of $\mathrm{ZnO} \mathrm{NPs}$, respectively.

Plant defence systems include antioxidant enzymes (peroxidases, SOD, catalase and ascorbate peroxidase) and antioxidant compounds (phenols, flavonoids, glutathione, carotenoids, among others) that can inhibit or reduce the production and effects of ROS (Ahmadi et al., 2019; Abbasifar et al., 2020; Hatamian et al., 2020). In this study, ZnO NPs sprays affected TP values in pods and seeds; however, only in the pods was the AC significantly affected with both $\mathrm{Zn}^{2+}$ sources (Table 2). Recent studies have demonstrated the positive effects of $\mathrm{Zn}^{2+}$ application in the form of $\mathrm{ZnO}$ NPs and conventional $\mathrm{ZnO}$ on the $\mathrm{AC}$ of tomato (Solanum licopersicum L.) (Akanbi-Gada et al., 2019) and habanero pepper (Capsicum chinense Jacq.) fruits (García-López et al., 2019). On the other hand, it has been observed that the application of $\mathrm{ZnO}$ NPs alone promotes the generation of ROS near the particle surface; however, their lifetime is short and they are eliminated by antioxidant agents (Pedruzzi et al., 2020). In this experiment, a low dose of $\mathrm{Zn}^{2+}\left(\mathrm{ZnSO}_{4}\right.$ and $\mathrm{ZnO}$ NPs) was used, which did not allow observation of the characteristic symptoms of phytotoxicity (necrosis and reduction of photosynthetic activity in leaflets), which confirms the importance of dose, number of applications and plant species to obtain positive effects on the physiology and biochemistry.

$P$. vulgaris $\mathrm{L}$. is one of the most important crops for human nutrition worldwide (Ewais et al., 2017). In this study, applications of $\mathrm{ZnSO}_{4}$ and $\mathrm{ZnO}$ NPs significantly increased both biomass $\left(79.10 \mathrm{~g} \cdot \mathrm{p}^{-1}\right.$ and $\left.84.70 \mathrm{~g} \cdot \mathrm{p}^{-1} \mathrm{DW}\right)$ and yield (55.64 $\mathrm{g} \cdot \mathrm{p}^{-1}$ and $53.80 \mathrm{~g} \cdot \mathrm{p}^{-1} \mathrm{FW}$ ) compared with the control (Figure 3). In this regard, it is important to note that $\mathrm{Zn}^{2+}$ is a micronutrient that plays important roles in photosynthesis, because it alters the chlorophyll concentrations and modifies (Ewais et al., 2017; Pullagurala et al., 2018; Shang et al., 2019). These results agree with those of Ponce-García et al. (2019) who, when evaluating soil applications of $25 \mathrm{mg} \cdot \mathrm{L}^{-1}$ $(\mathrm{ZnO} \mathrm{NPs})$ and $50 \mathrm{mg} \cdot \mathrm{kg}^{-1}\left(\mathrm{ZnSO}_{4}\right)$ reported increases of $42 \%$ and $35 \%$ of biomass respectively, compared with the control. On the other hand, the yield values were found to exceed those reported by Ponce-García et al. (2019) when applying soil doses of $50 \mathrm{mg} \cdot \mathrm{kg}^{-1}$ and $25 \mathrm{mg} \cdot \mathrm{kg}^{-1}$ of $\mathrm{ZnSO}_{4}$ and $\mathrm{ZnO} \mathrm{NPs}$, respectively. It has been reported that the efficiency of NPs is associated with the particle size, chemical structure, surface area covered and application rate (Aguilar-Carpio et al., 2018; Rossi et al., 2019; Ghidan et al., 2020). However, in this study the application of $\mathrm{ZnO}$ NPs and $\mathrm{ZnSO}_{4}$ showed similar behaviours. These behaviours may be associated with the solubilities and stabilisation of the acidic $\mathrm{pH}$ of the solution presented by $\mathrm{ZnSO}_{4}$ (Minnocci et al., 2018).

\section{CONCLUSIONS}

Foliar application of $\mathrm{ZnO}$ NPs increased the concentration of $\mathrm{Zn}^{2+}$ in leaflets, stems, roots and fruits. It also improved the foliar concentration of chlorophyll $(a$ and $b$ ), without variation in carotenoids and TAn. $\mathrm{ZnSO}_{4}$ was significant for sucrose, however, it did not exceed what was observed with the application of ZnO NPs. ZnO NP spraying affected the total phenolic values in pods and seeds, while $\mathrm{AC}$ was significant with both $\mathrm{Zn}^{2+}$ sources but only in pods. Plants treated with $\mathrm{ZnSO}_{4}$ and $\mathrm{ZnO}$ NPs accumulated a higher biomass $\left(79.1 \mathrm{~g} \cdot \mathrm{p}^{-1}\right.$ and $\left.84.70 \mathrm{~g} \cdot \mathrm{p}^{-1} \mathrm{DW}\right)$ and yield 
$\left(55.64 \mathrm{~g} \cdot \mathrm{p}^{-1}\right.$ and $\left.53.80 \mathrm{~g} \cdot \mathrm{p}^{-1} \mathrm{FW}\right)$. Foliar application of $\mathrm{ZnO}$ NPs could be an agronomic management strategy for biofortification with $\mathrm{Zn}^{2+}$ in green bean 'Strike' production.

\section{ACKNOWLEDGEMENTS}

The authors of this article thank Dr Jorge Jiménez Castro for his valuable assistance in the statistical analysis of the data.

\section{FUNDING}

This research was funded by the Faculty of Agrotechnological Sciences of the Universidad Autónoma de Chihuahua.

\section{AUTHOR CONTRIBUTIONS}

J.B.-D., O.C.-A., D.L.O.-B., E.S.-C., and O.A.H.-R. designed experiments and performed analytical measurements. J.B.-D., J.L.J.-C., D.L.O.-B., G.D.A.-Q., and P.P.-R. collection and statistical analysis of data. O.C.-A., D.L.O.-B., E.S.-C., and J.L.J.-C. writing and review of this paper.

\section{CONFLICT OF INTEREST}

The authors declare no conflict of interest.

\section{REFERENCES}

Abbasifar, A., Shahrabadi, F., and Valizadehkaji, B. (2020). Effects of green synthesized zinc and copper nanofertilizers on the morphological and biochemical attributes of basil plant. Journal of Plant Nutrition, 43(8), 1104-1118.

Aghaye-Noroozlo, Y., Souri, M. K., and Delshad, M. (2019). Effects of soil application of amino acids, ammonium, and nitrate on nutrient accumulation and growth characteristics of sweet basil. Communications in Soil Science and Plant Analysis, 50(22), 2864-2872.

Aguilar-Carpio, C., Juárez-López, P., CamposAguilar, I. H., Alia-Tejacal, I., Sandoval-Villa, M., And López-Martínez, V. (2018). Analysis of growth and yield of cape gooseberry (Physalis peruviana L.) grown hydroponically under greenhouse conditions. Revista Chapingo Serie Horticultura, 24(3), 191-202.

Ahmadi, M., And Souri, M. K. (2019). Nutrient uptake, proline content and antioxidant enzymes activity of pepper (Capsicum annuum L.) under higher electrical conductivity of nutrient solution created by nitrate or chloride salts of potassium and calcium. Acta Scientiarum Polonorum, Hortorum Cultus, 18(5), 113-122.

Akanbi-Gada, M. A., Ogunkunle, C. O., Vishwakarma, V., Viswanathan, K., and Fatoba, P. O. (2019). Phytotoxicity of nano-zinc oxide to tomato plant
(Solanum lycopersicum L.): Zn uptake, stress enzymes response and influence on non-enzymatic antioxidants in fruits. Environmental Technology \& Innovation, 14, 100325, doi: 10.1016/j. eti.2019.100325.

Aslani, M., And Souri, M. K. (2018). Growth and quality of green bean (Phaseolus vulgaris L.) under foliar application of organic chelate fertilizers. Open Agriculture, 3, 146-154.

Balafrej, H., Bogusz, D., Triqui, D. B., Guedira, A., Bendaou, N., Smouni, A., And Fahr, M. (2020). Zinc hyperaccumulation in plants: A review. Plants, 9, 562, doi: 10.3390/plants9050562.

Balandrán-Valladares, M. I., Cruz-Alvarez, O., Jacobo-Cuellar, J. L., Hernández-Rodríguez, O. A., Flores-Córdova, M. A., Parra-Quezada, R. A., SÁnchez-Chávez, E., and Ojeda-Barrios, D. L. (2021). Changes in nutrient concentration and oxidative metabolism in pecan leaflets at different doses of zinc. Plant, Soil and Environment, 67(1), 33-39.

Bonomelli, C., Alcalde, C., Aguilera, C., Videla, X., Rojas-Silva, X., Nario, A., and Fernández, V. (2021). Absorption and mobility of radio-labelled calcium in chili pepper plants and sweet cherry trees. Scientia Agricola, 78(6), doi: 10.1590/1678-992X2020-0092.

Castillo-González, J., Ojeda-Barrios, D., Hernández-Rodríguez, A., GonzÁlez-Franco, Robles-Hernández, L., And López-OchoA, G. R. (2018). ZINC METALLOENZYMES IN PLANTS. INTERCIENCIA, 43(4), 242-248

Cera-Campos, J. I., Jacobo-Cuellar, J. L., Rodríguez-Roque, M. J., Parra-Quezada, R. A., Soto-Caballero, M. C., Pérez-Leal, R., AND Cruz-Alvarez, O. (2019). Vegetative growth and quality of blueberry fruit cultivated in Chihuahua, Mexico. Notulae Botanicae Horti Agrobotanici Cluj-Napoca, 47(2), 450-457.

Chang, C., Yang, M., and Mchern, J. C. (2002). Estimation of total flavonoids content in propolis by two complementary colorimetric methods. Journal of Food and Drug Analysis, 10(3), 178-182.

Doolette, C., Read, T., Li, C., Scheckel, K., Donner, E., Schjoerring, J., And Lombi, E. (2018). Foliar application of zinc sulphate and zinc EDTA to wheat leaves: Differences in mobility, distribution, and speciation. Journal of Experimental Botany, 69, 4469-4481.

Ebrahimi, M., Souri, M. K., Mousavi, A., And SAHEBANI, N.(2021). Biochar and vermicompost improve growth and physiological traits of eggplant (Solanum melongena L.) under deficit irrigation. Chemical and Biological Technologies in Agriculture, 8(1), 19, doi: 10.1186/s40538-02100216-9.

Ewais, A. E., Ismail, A. M., And Badawy, A. A. (2017). Vegetative growth, photosynthetic pigments and 
yield of Phaseolus vulgaris (L.) plants in response to the application of biologically-synthesized zinc oxide nanoparticles and zinc sulfate. Paper presented at the 9th International Conference Basic Sciences, Energy, Environment and Sustainable, Cairo, Egypt, 33-46.

Fatollahpour-Grangah, M., Rashidi, V., Mirshekari, B., Khalilvand-Behrouzyar, E., and Farahvash, F. (2020). Effects of nano-fertilizers on physiological and yield characteristics of pinto bean cultivars under water deficit stress. Journal of Plant Nutrition, 43(19), 2898-2910.

García-Caparrós, P., Lao, M. T., Preciado-Rangel, P., AND SAnchez, E. (2021). Phosphorus and carbohydrate metabolism in green bean plants subjected to increasing phosphorus concentration in the nutrient solution. Agronomy, 11(2), 245, doi: 10.3390/agronomy11020245.

García-López, J. I., Niño-Medina, G., Olivares-Sáenz, E., Lira-Saldivar, R. H., Barriga-Castro, E. D., Vázquez-Alvarado, R., Rodríguez-Salinas, P. A., And Zavala-García, F. (2019). Foliar application of zinc oxide nanoparticles and zinc sulfate boosts the content of bioactive. Plants, 8, 254. doi: 10.3390/ plants8080254.

Ghidan, A. Y., Kahlel, A. M. S., Al-Antary, T. M., And Asoufi, H. M. (2020). Efficacy of nanotechnology liquid fertilizers on weight and chlorophyll of broad bean (Vicia faba L.). Fresenius Environmental Bulletin, 29(6), 4789-4793.

Giusti, M. M., And Wrolstad, R. E. (2001). Characterization and measurement of anthocyanins by UV-visible spectroscopy. In: R. E. Wrolstad, T. E. Acree, H. An, E. A., Decker, M. H. Penner, D. S. Reid, S. J. Schwartz, C. F. Shoemaker and P. Sporns (Eds). Current protocols in food analytical chemistry (pp. F1.2.1-F1.2.13). New York, USA: John Wiley \& Sons.

Hatamian, M., Rezaei-Nejad, A., Kafi, M., Souri, M. K., AND ShahbaZI, K. (2020). Interaction of lead and cadmium on growth and leaf morphophysiological characteristics of European hackberry (Celtis australis) seedlings. Chemical and Biological Technologies in Agriculture, 7(1), 9, doi: 10.1186/ s40538-019-0173-0.

Hatamian, M., Rezaie-Nejad, A., Kafi, M., Souri, M. K., And Shahbazi, K. (2018). Interactions of lead and nitrate on growth characteristics of ornamental judas tree (Cercis siliquastrum). Open Agriculture, 3, 386-392.

Irigoyen, J. J., Einerich, D. W., And SÁnchez-Díaz, M. (1992). Water stressinduced changes in concentrations of proline and total soluble sugars in nodulated alfalfa (Medicago sativa) plants. Physiologia Plantarum, 84(1), 55-60.

Korkmaz, K., Kirl, A., Akgün, M., and Dede, O. (2018). Effects of different levels of foliar zinc and application time on total phenolic content and antioxidant activity of potato. Fresenius Environmental Bulletin, 27(6), 4192-4197.

Marzouk, N. M., Abd-Alrahman, H. A., El-Tanahy, A. M. M., And Mahmoud, S. H. (2019). Impact of foliar spraying of nano micronutrient fertilizers on the growth, yield, physical quality, and nutritional value of two snap bean cultivars in sandy soils. Bulletin of the National Research Centre, 43, 84, doi: 10.1186/ s42269-019-0127-5.

Mazaheri-Tirani, M., Madadkar-Haghjou, M., and Ismaili, A. (2019). Hydroponic grown tobacco plants respond to zinc oxide nanoparticles and bulk exposures by morphological, physiological and anatomical adjustments. Functional Plant Biology, 46, 360-375.

Minnocci, A., Francini, A., Romeo, S., Sgrignuoli, A. D., Poverob, G., and Sebastiani, L. (2018). Zn-localization and anatomical changes in leaf tissues of green beans (Phaseolus vulgaris L.) following foliar application of $\mathrm{Zn}$-lignosulfonate and ZnEDTA. Scientia Horticulturae, 231, 15-21.

Monroy-Gutiérrez, T., Martínez-Damián, M., Barrientos-Priego, A., Gallegos-Vázquez, C., Cruz-Alvarez, O., and Vargas-Madríz, H. (2017). Bioactive compounds and antioxidant capacity in fruits of xocotuna, cactus pear and xoconostle (Opuntia spp.). Chilean Journal of Agricultural and Animal Sciences, 33(3), 263-272.

Nafady, N., Alamri, S., Hassan, E., Hashem, M., Mostafa, Y., And Abo-Elyousr, K. (2019). Application of $\mathrm{ZnO}$-nanoparticles to manage Rhizopus soft rot of sweet potato and prolong shelflife. Folia Horticulturae, 31(2), 319-329.

Ojeda-Barrios, D. L., Morales, I., Juárez-Maldonado, A., Sandoval-Rangel, A., Fuentes-Lara, L. O., and Benavides-MendozA, A. (2019). Importance of nanofertilizers in fruit nutrition. In A. K. Srivastava and C. Hu (Eds), Fruits crops: Diagnosis and management of nutrient constraints (pp. 497-506). USA: Elsevier Science Publishing Co. Inc.

Pedruzzi, D. P., Araujo, L. O., Falco, F. W., Machado, G., Casagrande, G. A., Colbecke, I., Lawsone, T., Oliveira, S. L., and Caires, A. R. L. (2020). $\mathrm{ZnO}$ nanoparticles impact on the photosynthetic activity of Vicia faba: Effect of particle size and concentration. NanoImpact, 19, 100246, doi: 10.1016/j.impact.2020.100246.

Ponce-García, C. O., Soto-Parra, J. M., Sánchez, E., Muñoz-Márquez, E., Piña-Ramírez, F. J., FloresCórdova, M. A., Pérez-Leal, R., And Yáñez-Muñoz, R. M. (2019). Efficiency of nanoparticle, sulfate, and zinc-chelate use on biomass, yield, and nitrogen assimilation in green beans. Agronomy, 9, 128, doi: 10.3390/agronomy9030128.

Pullagurala, V. L. R., Adisa, I. O., Rawat, S., Kalagara, S., Hernandez-Viezcas, J. A., PeraltaVidea, J. R., And Gardea-Torresdey, J. L. (2018). $\mathrm{ZnO}$ nanoparticles increase photosynthetic pigments 
and decrease lipid peroxidation in soil grown cilantro (Coriandrum sativum). Plant Physiology and Biochemistry, 132, 120-127.

Raliya, R., Saharan, V., Dimkpa, C., and Biswas, P. (2018). Nanofertilizer for precision and sustainable agriculture: Current state and future perspectives. Journal of Agricultural and Food Chemistry, 66(26), 6487-6503.

Rossi, L., Fedenia, N. L., Sharifan, H., Ma, X., and LOMBARDini, L. (2019). Effects of foliar application of zinc sulfate and zinc nanoparticles in coffee (Coffea arabica L.) plants. Plant Physiology and Biochemistry, 135, 160-166.

Sálcido-Martínez, A., Sánchez, E., Licon-Trillo, L. P., Pérez-Alvarez, S., Palacio-Márquez, A., AmayaOlivas, N. I., And Preciado-Rangel, P. (2020). Impact of the foliar application of magnesium nanofertilizer on physiological and biochemical parameters and yield in green beans. Notulae Botanicae Horti Agrobotanici Cluj-Napoca 48(4), 2167-2181.

Shang, Y., Kamrul-Hasan, Md., Jalal-Ahammed, G., Li, M., Yin, H., AND ZHOU, J. (2019). Applications of nanotechnology in plant growth and crop protection: A review. Molecules, 24, 2558, doi: 10.3390/ molecules24142558.

Sida-Arreola, J. P., SÁnchez-Chávez, E., ÁvilaQuezada, G. D., Zamudio-Flores, P. B., And Acosta, M. C. (2015). Iron biofortification and its impact on antioxidant system, yield and biomass in common bean. Plant, Soil and Environment, 61(12), 573-576.

Singh, A., Singh, N. B., Afzal, S., Singh, T., And Hussain, I. (2017). Zinc oxide nanoparticles: A review of their biological synthesis, antimicrobial activity, uptake, translocation and biotransformation in plants. Journal of Materials Science, 53, 185-201.

Sokal, R. R., And Rohlf, F. J. (1995). Biometry: The principles and practice of statistics in biological research. New York, USA: W.H. Freeman \& Co. Ltd.
Souri, M. K., AND Aslani, M. (2018). Beneficial effects of foliar application of organic chelate fertilizers on French bean production under field conditions in a calcareous soil. Advances in Horticultural Science, 32(2), 265-272.

Souri, M. K., AND Dehnavard, S. (2017). Characterization of tomato growth and fruit quality under foliar ammonium sprays. Open Agriculture, 2(1), 531-536.

Souri, M. K., and Hatamian, M. (2019). Aminochelates in plant nutrition; A review. Journal of Plant Nutrition, 42(1), 67-78.

Souri, M. K., Hatamian, M., and Tesfamariam, T. (2019). Plant growth stage influences heavy metal accumulation in leafy vegetables of garden cress and sweet basil. Chemical and Biological Technologies in Agriculture, 6(1), 25.

Souri, M. K., NAIJ, M., AND Aslani, M. (2018). Effect of Fe-glycine aminochelate on pod quality and iron concentrations of bean (Phaseolus vulgaris L.) under lime soil conditions. Communications in Soil Science and Plant Analysis, 49(2), 215-224.

Souri, M. K., Sooraki, F. Y., And Moghadamyar, M. (2017). Growth and quality of cucumber, tomato, and green bean under foliar and soil applications of an aminochelate fertilizer. Horticulture, Environment, and Biotechnology, 58(6), 530-536.

Zafar, H., Ali, A., Ali, J. S., Haq, I. U., And Zia, M. E. (2016). Effect of $\mathrm{ZnO}$ nanoparticles on Brassica nigra seedlings and stem explants: Growth dynamics and antioxidative response. Frontiers in Plant Sciences, 7, 535, doi: 10.3389/fpls.2016.00535.

Zargar S. F., Souri, M. K., Hasandokht, M. R. And Kalate, J. S. (2020). Glycine mitigates fertilizer requirements of agricultural crops: Case study with cucumber as a high fertilizer demanding crop. Chemical and Biological Technologies in Agriculture, 7(1), 19, doi: 10.1186/s40538-020-00 185-5.

Received: May 12, 2021; accepted: November 29, 2021. 